20405

\title{
遮熱コーティングの皮膜特性に及ぼす溶射条件と高温曝露条件の影響
}

\section{Influence of Thermal Spraying Condition and High-temperature Exposure Condition on Coating Properties of Thermal Barrier Coatings}

\author{
○学 和田 英志 (東工大院) \\ 正 荒井 正行 (電中研) \\ 正 岸本喜久雄（東工大） \\ 大野 直行 (プラズマ技研)
}

Eiji WADA, Tokyo Institute of Technology, 2-12-1 O-okayama, Meguro-ku, Tokyo

Masayuki ARAI, Central Research Institute of Electric Power Industry, 2-11-1 Iwado kita, Komae-shi, Tokyo Kikuo KISHIMOTO, Tokyo Institute of Technology, 2-12-1 O-okayama, Meguro-ku, Tokyo

Naoyuki OHNO, PLASMA GIKEN CO.,LTD., 2-1-12 Bijogi, Toda-si, Saitama

\begin{abstract}
Thermal Barrier Coating (TBC) is fabricated by thermal spray technology. In this technology, coating particles are melted in high-temperature plasma flow, impinged and deposited continuously to a substrate surface. Since a coating layer is formed by this way, it seems that the microstructure and the mechanical properties of TBC are affected by the spray condition and high-temperature environment in service. In this study, the substrate temperature and the particle velocity of the coating particle in plasma flow as the spray condition are varied. Coefficient of thermal expansion, elastic modulus, crack length, Vickers hardness, porosity, bending strength and residual stress of the ceramic layer are measured for as-sprayed specimen. In addition, thermal exposure tests are conducted to examine influence of exposure temperature on the mechanical properties of TBC.
\end{abstract}

Key Words : Thermal Barrier Coating, Plasma Spray, Spray Condition, Heat Treatment

\section{1 緒言}

発電用ガスタービンでは、効率向上のために第一段静翼の 入口温度高温化がおこなわれており，高温ガスからの基材保 護のためにプラズマ溶射法によって遮熱コーティングが施 されている. プラズマ溶射法では, 高速高温のプラズマ流内 で粒子状のコーティング材が溶融または半溶融状態まで加 熱され，連続的に基材表面に衝突・堆積することで皮膜が形 成される.このため，溶射皮膜の膜質ならびにその機械的特 性は，溶射条件によって変化するものと考えられる.さらに， 作製された皮膜が高温大気中に長時間曝露されることもま た，その特性に大きく影製を及ぼすことが知られている．し かし，そのような影響について系統的に調査した研究はこれ まで見当たらない.

そこで, 本研究では, 溶射条件と高温曝露条件が溶射皮膜 の各種特性值におよぼす影響を調べた。

\section{2 溶射皮膜の特性䚴查}

2.1 供試材および容射条件と高温曝震条件 測定試料に供 した材料は, トップコーティング層を部分安定化ジルコニア $\left(8 \mathrm{wt} \% \mathrm{Y}_{2} \mathrm{O}_{3}-\mathrm{ZrO}_{2} ; 204 \mathrm{NS} \mathrm{METCO}\right)$, ボンドコーティング層を CoNiCrAlY(PRAXAIR, CO-210-1)，基材をステンレス鎆とし

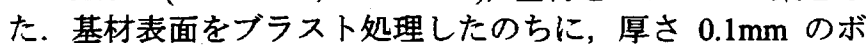
ンドコーティング層, 厚さ $1.0 \mathrm{~mm}$ のトップコーティング層 を大気プラズマ溶射によって堆積させた. 溶射条件としては,

Table.1 Spray condition

\begin{tabular}{|c|c|c|}
\hline & 基材温度 & 粒子速度 \& 温度 \\
\hline 条件 1 & 高温 $(600 \mathrm{~K})$ & 中 $\quad(175 \mathrm{~m} / \mathrm{s} \& 3628 \mathrm{~K})$ \\
\hline 条件 2 & 低温 （380K） & 中 $(175 \mathrm{~m} / \mathrm{s} \& 3628 \mathrm{~K})$ \\
\hline 条件 3 & 中温 $(470 \mathrm{~K})$ & 中 $(175 \mathrm{~m} / \mathrm{s} \& 3628 \mathrm{~K})$ \\
\hline 条件 4 & 高温 (520K) & 低 $(146 \mathrm{~m} / \mathrm{s} \& 3521 \mathrm{~K})$ \\
\hline 条件 5 & 高温 $\quad(600 \mathrm{~K})$ & 高 $\quad(198 \mathrm{~m} / \mathrm{s} \& 3718 \mathrm{~K})$ \\
\hline
\end{tabular}

溶射中の基材温度と, プラズマ流のエネルギーによって変化 させたコーティング粒子の温度・速度に関する，二つの条件 とした，Table.1に設定した条件を示す．あわせて，皮膜作製

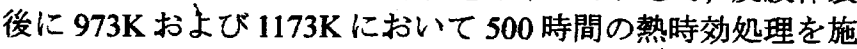
し，高温嚗露による皮膜の特性変化についても調査した。

2.2 特性調査 溶射条件·熱時効条件の異なる皮膜について, 線膨張係数と四点曲げ試験による縦弾性係数の測定をおこ なった．また，ビッカース硬さの測定およびその圧子によっ て発生したき裂長さの測定, 溶射皮膜断面の顕微鏡写真によ る気孔率測定，四点曲げ試験による曲げ強度測定も行い，粒 子の堆積形態や粒子間の密着性について調べた。さらに、ひ ずみゲージ法によってセラミックコーティング層の残留応 力を測定した.

2.3 調查結果 測定結果を Fig.1，2 にまとめて示す.

2.3.1. 線膨張係数 溶射条件, 熱時効条件によって線膨張 係数に大きな変化はみられず，それらの影響は小さいことが わかった。
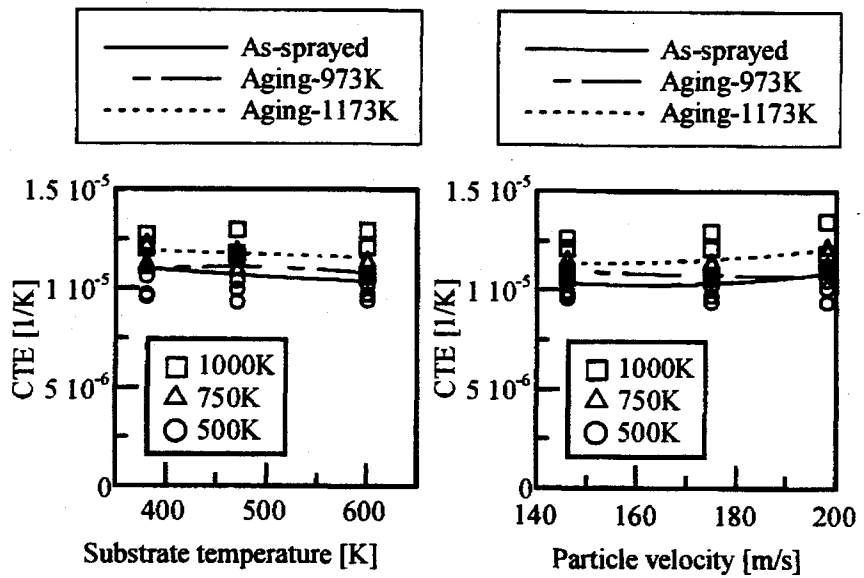

Substrate temperature $[\mathrm{K}]$

Fig.1 Effect of aging on coefficient of thermal expansion.

日本機械学会関東支部第 13 期総会講演会講演論文集 ['07 - 3.16,17, 宇都宮市] 
2.3.2. 気孔率溶射条件が気孔率に及ぼす影響においては, 基材温度が高く, 粒子速度が速くなるにつれて気孔率は低下 していく．これに対し，熱時効によって気孔率はやや上昇す るようである、これは，熱時効における高温状態において基 材が熱膨張し，多数の気孔が開孔したためと考えられた。

2.3.3. き裂長さ 溶射条件がき裂長さに及ぼす影響につい て注目すると, 基材温度においては大きな変化は認められな いが，粒子速度の上昇に伴いき裂長さは小さくなった．すな わち，粒子間の密着力が上昇したといえる。これに対して， 熱時効すると，973K において顥著な変化が認められる．す なわち，き裂長さが溶射条件によらず小さくなり，界面に垂 直方向の粒子間の密着力が上昇した。一方, $1173 \mathrm{~K} て ゙ は ，$ As-sprayed 材と同様であった。

2.3.4. ビッカース硬さ 溶射条件がビッカース硬さに及ぼ 寸影響としては，粒子速度の上界に伴いビッカース硬さは上 昇するが，基材温度ではいったん上昇したのちに低下した． この変化傾向は熱時効後も同様であるが, 熱時効によってそ の值は大きく上昇した．特に 973K での熱時効による上昇は 顥著であり，これは熱時効によるき裂長さの減少にみられる 粒子間密着力の上昇が大きく影警したものと考えられる。

2.3.5. 緥弹性係数 溶射条件が縦弾性係数に及ぼす影響に おいては，基材温度では大きな変化は認められないが，粒子 速度の上昇に伴って縦弾性係数は増加した。 これに対して,
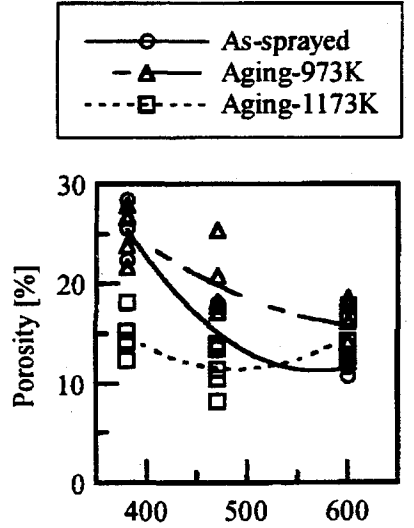

Substrate temperature [K]

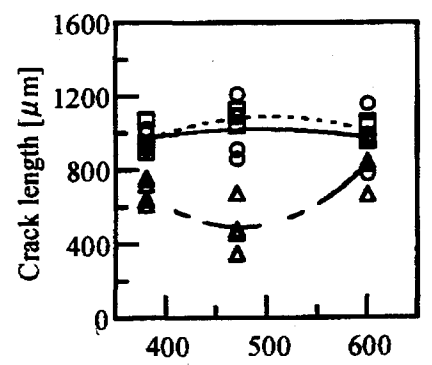

Substrate temperature [K]

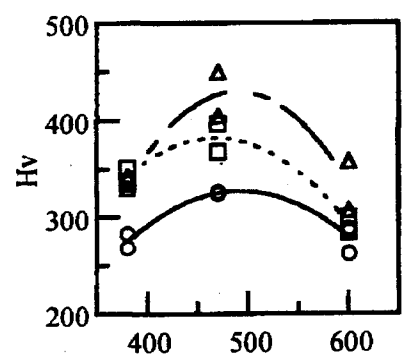

Substrate temperature [K]
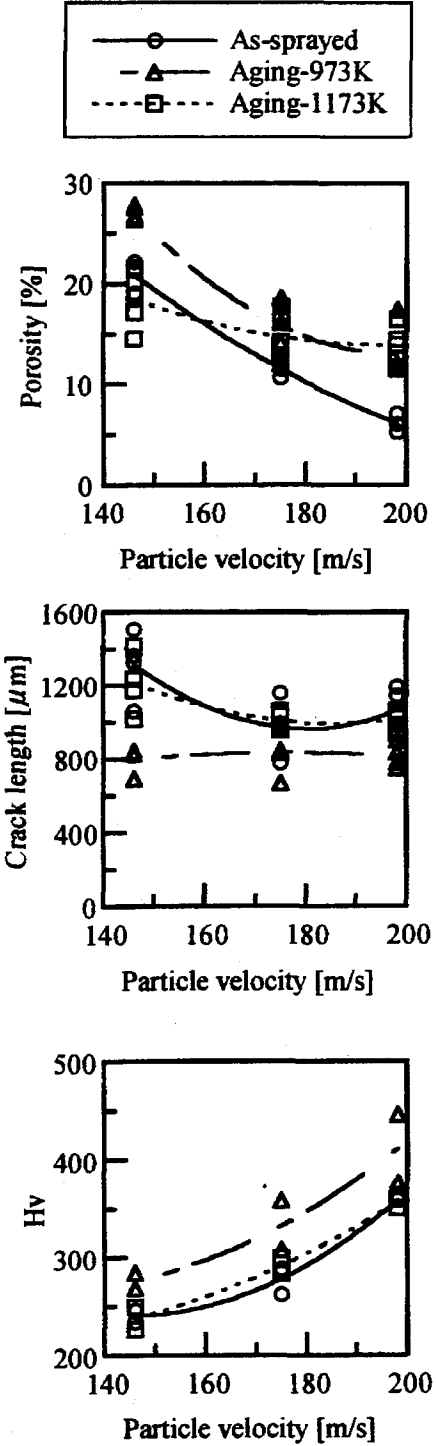

熱時効によって絴弾性俰数はやや低下寸るようである.これ は熱時效による気孔率上昇によって実際の断面積が低下し たためと考えられる。

2.3.6 曲げ強度 溶射条件が曲げ強度に及ほす影製におい ては，基材温度・粒子速度の上昇に伴って曲げ強度は増加し た、すなわち，界面に平行な方向の粒子間密着力か上昇した といえる。これに対して，熱時効すると曲げ強度は大きく低 下した。これは，熱時效によって増加した気孔率や割れなど， 皮膜内部の欠陷の増大によってコーティング層としての巨 視的な強度が減少したためと考えられる。

2.3.7 残留応力 溶射条件が残留応力に及ぼす影製として は，基材温度・粒子速度の上昇に伴い圧樎側への変化が認め られた。また，熱時効によっても残留応力は大きく圧縮側に 変化し, 特に $1173 \mathrm{~K}$ の熱時効では $100 \mathrm{MPa}$ 程度の応力変化が 認められる。こは曲げ試験において負荷後に認められた氷 久ひずみにみられる，コーティング層の非弾性举動に起因し ていると考えられる。つまり，高温状態で，基材との線膨張 係数差に起因する引張忘力が長時間作用することで皮膜が 伸長し，室温に送ったときに発生する熱応力が圧縮側に大き くシフトしたことによると考えられる。

\section{3 結言(省略)}

考支文献(省略)
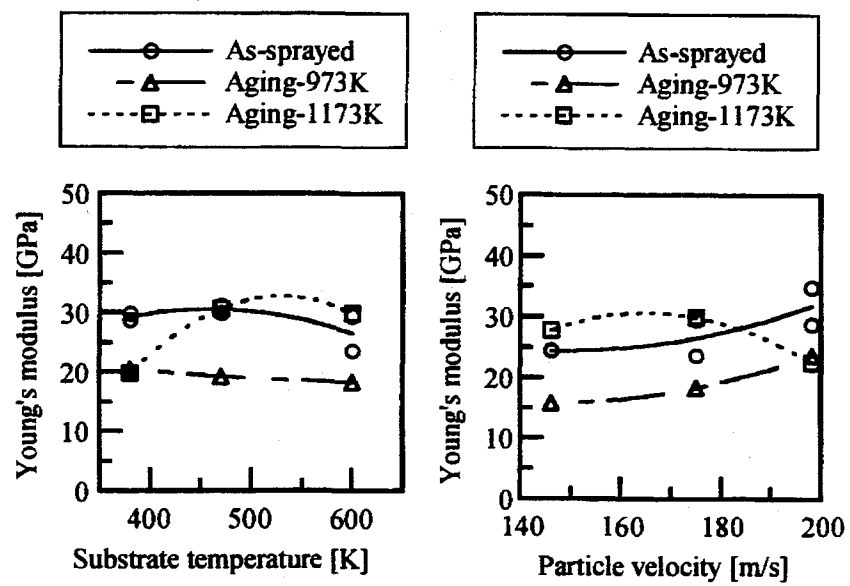

Substrate temperature $[\mathrm{K}]$
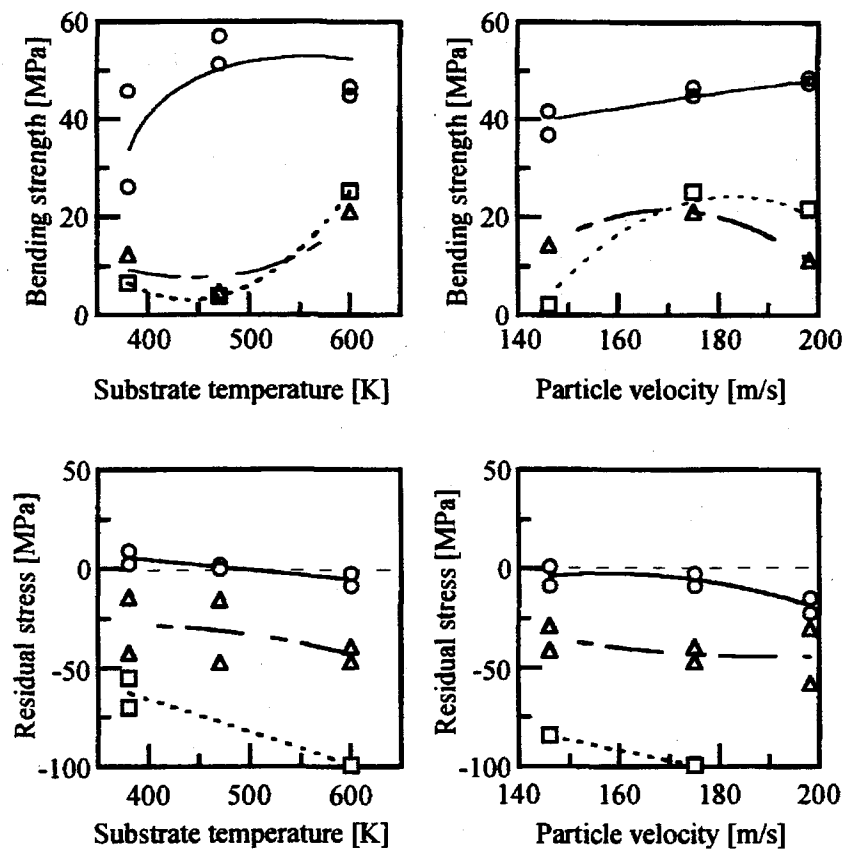

Fig.2 Effect of aging on coating properties. 